JURNAL PENDIDIKAN, p-ISSN 2715-095X, e-ISSN 2686-5041

Volume 30, No.3, Nopember 2021 (471-480)

Online: http://journal.univetbantara.ac.id/index.php/jp

\title{
Peningkatan Prestasi Belajar IPA dengan Penerapan Model Pembelajaran Kooperatif Tipe Think Pair Share pada Siswa Kelas IXA SMP Negeri 5 Sukoharjo Semester I Tahun Pelajaran 2017/2018
}

\author{
Harun Purwanto
}

SMP Negeri 5 Sukoharjo, E-mail: Purwantoharun26@gmail.com

Received: Juli 16, $2021 \quad$ Accepted: Oktober 24, $2021 \quad$ Online Published: Nopember 08, 2021

\begin{abstract}
Abstrak: Penelitian ini bertujuan untuk meningkatkan prestasi belajar IPA kelas IX A SMP Negeri 5 Sukoharjo tahun pelajaran 2017/ 2018 dengan penerapan model pembelajaran kooperatif tipe TPS. Penelitian ini adalah Penelitian Tindakan Kelas (PTK) yang dilaksanakan di kelas IX A SMP Negeri 5 Sukoharjo, semester I tahun pelajaran 2017/ 2018, dengan jumlah siswa sebanyak 32 orang. Teknik pengumpulan data yang digunakan adalah tes, observasi, dan dokumentasi. Tahap-tahap analisis data dalam penelitian ini adalah pengumpulan data, reduksi data, penyajian data, dan penarikan kesimpulan. Berdasarkan penelitian yang telah dilakukan, dapat disimpulkan bahwa dengan model pembelajaran kooperatif tipe TPS dapat meningkatkan prestasi belajar IPA pada siswa kelas IX A SMP Negeri 5 Sukoharjo. Hal ini dapat dilihat dari persentase ketuntasan belajar siswa, yaitu: sebelum tindakan 12 siswa atau $37,5 \%$, pada siklus I sebanyak 23 siswa atau $72,2 \%$ dan pada siklus II sebanyak 30 siswa atau 93,8\%. Sedangkan rata-rata prestasi belajar IPA siswa sebelum tindakan sebesar 71,2, pada siklus I sebesar 77,2, dan pada siklus II sebesar 81,8.
\end{abstract}

Kata-kata Kunci: model pembelajaran kooperatif tipe TPS, prestasi belajar IPA.

\section{Improving Science Learning Achievement by Applying Cooperative Learning Model Type Think Pair Share in Class IXA Students of SMP Negeri 5 Sukoharjo Semester I 2017/2018 Academic Year}

\author{
Harun Purwanto
}

\author{
SMP Negeri 5 Sukoharjo, E-mail: Purwantoharun26@gmail.com
}

\begin{abstract}
This study aims to improve science learning achievement in class IX A of SMP Negeri 5 Sukoharjo in the 2017/2018 academic year by applying the TPS type cooperative learning model. This research is a Classroom Action Research (CAR) conducted in class IX A of SMP Negeri 5 Sukoharjo, first semester of the 2017/2018 academic year, with a total of 32 students. Data collection techniques used are tests, observations, and documentation. The stages of data analysis in this study are data collection, data reduction, data presentation, and drawing conclusions. Based on the research that has been done, it can be concluded that the TPS type cooperative learning model can improve science learning achievement in class IX A students of SMP Negeri 5 Sukoharjo. This can be seen from the percentage of student learning completeness, namely: before the action 12 students or $37.5 \%$, in the first cycle as many as 23 students or $72.2 \%$ and in the second cycle as many as 30 students or $93.8 \%$. While the average science learning achievement of students before the action was 71.2, in the first cycle of 77.2, and in the second cycle of 81.8 .
\end{abstract}

Keywords: TPS type cooperative learning model, science learning achievement. 


\section{Pendahuluan}

Proses pembelajaran IPA tidak selamanya berjalan efektif karena masih ada beberapa siswa yang mengalami kesulitan dalam belajar IPA. Banyak siswa memandang pelajaran IPA adalah pelajaran yang sulit sehingga kurang dinikmati dan bahkan dihindari oleh sebagian siswa. Hal itu menyebabkan rendahnya prestasi belajar IPA siswa. Rendahnya prestasi belajar IPA siswa disebabkan karena pada umumnya guru menggunakan model pembelajaran konvensional. Model pembelajaran konvensional untuk mata pelajaran IPA tentu tidak relevan dan akan menimbulkan kesenjangan bagi pemahaman siswa. Dalam pembelajaran menggunakan model konvensional sebenarnya bukan sejauh mana siswa paham dengan materi yang diajarkan tetapi sejauh mana guru bisa menyampaikan materi itu. Sehingga siswa hanya mendengar apa yang diterangkan oleh guru yang akhirnya siswa tidak terbiasa mengemukakan ide-ide atau gagasan yang ada dalam pikirannya. Inilah yang membuat siswa menjadi pasif dan akhirnya malas untuk mengembangkan kemampuan berfikirnya. Hal tersebut dapat mengakibatkan proses belajar yang telah disajikan oleh guru menjadi tidak tuntas dan tidak paham dengan materi tersebut.

Berkaitan dengan hal tersebut, permasalahan yang sama terjadi di SMP Negeri 5 Sukoharjo dimana kegiatan pembelajaran hanya berpusat pada guru sehingga kegiatan belajar mengajar menjadi kurang menarik sehingga kurang diminati siswa. Berdasarkan hasil ulangan IPA materi Sistem ekskresi pada manusia pada siswa kelas IX A SMP Negeri 5 Sukoharjo, didapatkan 37,5\% siswa yang tuntas melebihi KKM dan rata-rata nilai 71,7. Jumlah siswa kelas IX A sebanyak 32 siswa, KKM IPA di SMP Negeri 5 Sukoharjo adalah 70. Setiap guru tentunya menginginkan pada saat proses belajar mengajar terjadi suatu interaksi antara guru dan siswa maupun antar sesama siswa. Hal ini menunjukkan bahwa dalam proses belajar mengajar dikelas siswa lebih bersemangat. Dengan kondisi tersebut guru akan lebih mudah dalam menyampaikan materi pelajaran karena pada siswa akan merespon dan memahami dengan baik. Prestasi belajar IPA pun dapat mengalami peningkatan. Untuk meningkatkan kemampuan berfikir dan aktivitas siswa sehingga prestasi belajar IPA dapat meningkat yakni perlu adanya variasi dalam proses belajarnya (Suwarto, 2013, 2017). Adanya variasi pembelajaran agar siswa bisa lebih bersemangat dalam proses kegiatan belajar mengajar didalam kelas. Model pembelajaran yang bervariasi tersebut artinya dalam penggunaan model mengajar tidak harus selalu sama untuk setiap pokok bahasan karena bisa saja terjadi bahwa suatu model tertentu cocok untuk satu pokok bahasan namun tidak cocok untuk pokok bahasan yang lain. Salah satu variasi dalam pembelajaran yakni dengan menerapkan model pembelajaran kooperatif. Model pembelajaran kooperatif sangat banyak macamnya, tetapi dalam hal ini penulis menggunakan model pembelajaran kooperatif tipe TPS (Think Pair Share) dalam pembelajaran IPA.

Belajar merupakan suatu proses perubahan tingkah laku sebagai hasil interaksi individu dengan lingkungannya dalam memenuhi kebutuhan hidupnya. Santrock dan Yussen (Sugihartono,2007:74) mendefinisikan belajar sebagai perubahan yang relatif permanen karena adanya pengalaman. Reber (Sugihartono, 2007: 74) mendefinisikan belajar dalam 2 pengertian. Pertama, belajar sebagai proses memperoleh pengetahuan dan 
kedua, belajar sebagai perubahan kemampuan bereaksi yang relatif langgeng sebagai hasil latihan yang diperkuat. Witherington(Hamdani, 2011: 21) mengemukakan belajar merupakan perubahan dalam kepribadian yang dimanifestasikan sebagai pola-pola respon yang baru berbentuk ketrampilan, sikap, kebiasaan, pengetahuan, dan kecakapan. Thursan Hakim (Hamdani, 2011: 21) mengemukakan bahwa belajar adalah suatu proses perubahan dalam kepribadian manusia, dan perubahan tersebut ditampakkan dalambentuk peningkatan kualitas dan kuantitas tingkah laku, seperti peningkatan kecakapan, pengetahuan, sikap, kebiasaan, pemahaman, keterampilan daya pikir dan lain-lain.Menurut Ernest R. Hilgard dalam(Sumardi Suryabrata,1984:252) belajar merupakan proses perbuatan yang dilakukan dengan sengaja, yang kemudian menimbulkan perubahan, yang keadaannya berbeda dari perubahan yang ditimbulkan oleh lainnya. Belajar menurut Santoso (2017: 41) merupakan suatu proses yang terjadi pada semua orang untuk memperoleh suatu perubahan tingkah laku, pengetahuan, dan ketrampilan yang mencakup ranah kognitif, efektif, dan psikomotor yang berlangsung terus menerus. Belajar itu bukan hanya sebatas kegiatan membaca, mendengarkan, menulis, mengerjakan tugas dan ulangan saja tetapi adanya perubahan tingkah laku dari hasil kegiatan proses belajar, dimana didalam proses belajar itu ada interaksi aktif dengan lingkungan dan perubahan tersebut bersifat permanen (Setiawati, 2018: 33). Menurut Purwadarminta (Hamdani, 2011: 137), prestasi adalah hasil yang telah dicapai (dilakukan, dikerjakan dan sebagainya). Sedangkan menurut Winkel (Hamdani, 2011: 138) mengemukakan bahwa prestasi belajar merupakan bukti keberhasilan yang telah dicapai oleh seseorang. Dengan demikian, prestasi belajar merupakan hasil maksimum yang dicapai oleh seseorang setelah melaksanakan usaha-usaha belajar.Prestasi belajar menurut Pratiwi (2015: 83) adalah perubahan yang diperoleh siswa setelah mengalami proses pembelajaran untuk mencapai tujuan pembelajaran yang diwujudkan dalam bentuk perbuatan. Perubahan ini biasanya dapat dilihat dari beberapa ranah, yaitu kognitif, afektif, dan psikomotorik pada diri siswa, untuk mengetahui hasilnya dapat diukur melalui tes ataupunpengamatan secara langsung.

Jadi, prestasi belajar adalah hasil pengukuran dari penilaian usaha belajar yang dinyatakan dalam bentuk simbol, huruf maupun kalimat yang menceritakan hasil yang sudah dicapai oleh setiap anak pada periode tertentu (Hamdani, 2011: 138). Sedangkan, Alamsyah (2016: 156) beranggapan bahwa prestasi belajar adalah hasil pengukuran dari penilaian usahabelajar yang dinyatakan dalam bentuk simbol, huruf maupun kalimat yang menceritakan hasil yang sudah dicapai oleh setiap anak pada periode tertentu. Prestasi belajar merupakan hasil dari pengukuran terhadap peserta didik yang meliputi faktor kognitif, afektif dan psikomotor setelahmengikuti proses pembelajaran yang diukur dengan menggunakan instrumen tes yang relevan. Dapat diambil kesimpulan bahwa prestasi belajar IPA adalah hasil belajar yang dicapai siswa dalam proses belajar mengajar yang ditunjukkan dengan nilai tes yang diberikan oleh guru, sehingga terdapat proses perubahan dalam pemikiran serta tingkah laku pada mata pelajaran IPA.

Pembelajaran adalah sesuatu yang dilakukan oleh siswa, bukan dibuat untuk siswa. Pembelajaran pada dasarnya merupakan upaya pendidik untuk membantu peserta didik melakukan kegiatan belajar (Isjoni, 2007: 11). Sedangkan, pembelajaran menurut Sunhaji (2014:34) merupakan aktivitas interaksi edukatif antara guru dengan peserta didik dengan didasari oleh adanya tujuan baik berupa pengetahuan, sikap maupun ketrampilan. Menurut Hamdani (2011: 80), model pembelajaran adalah cara yang digunakan guru untuk menyampaikan pelajaran kepada siswa. Karena penyampaian itu berlangsung dalam interaksi idukatif, Model pembelajaran dapat diartikan sebagai cara yang dipergunakan oleh 
guru dalam mengadakan hubungan dengan siswa pada saat berlangsungnya pengajaran. Dengan demikian, model pembelajaran merupakan alat untuk menciptakan proses belajar mengajar.

Menurut H. Karli dan Yuliariatiningsih (Hamdani, 2011: 165), model pembelajaran kooperatif adalah suatu strategi belajar mengajar yag menekankan pada sikap atau perilaku bersama dalam bekerja atau membantu diantara sesama dalam struktur kerja sama yang teratur dalam kelompok, yang terdiri atas dua orang atau lebih. Sedangkan menrut Sjafei (2017: 29) pembelajaran kooperatif merupakan strategi belajar dengan sejumlah peserta didik sebagai anggota kelompok kecil yang tingkat kemampuannya berbeda. Model pembelajaran ini dibentuk dalam kelompok kecil antara 4-6 orang peserta didik sebagai bentuk aktivitas belajar dan bekerja secara kolaboratif. Keberhasilan kerja sangat dipengaruhi keterlibatan setiap anggota kelompok itu sendiri. Pembelajaran kooperatif dapat menjadikan siswa berinteraksi antar peserta didik untuk saling memberi pengetahuannya dalam memecahkan suatu masalah yang disajikan guru sehingga

semua peserta didik akan lebih mudah memahami berbagai konsep, Membuat suasana penerimaan terhadap sesama peserta didik yang berbeda latar belakang misalnya suku, sosial, budaya, dan kemampuan (Hasanah, 2021: 11).

Siti F (2009) menyatakan bahwa model pembelajaran kooperatif tipe Think Pair and Share (TPS) merupakan salah satu tipe pembelajaran kooperatif yang dikembangkan oleh Frank Lyman, dkk dari Universitas Maryland pada tahun 1985 sebagai salah satu struktur kegiatan cooperative learning. Think pair and share (tps)memberikan waktu kepada para siswa untuk berpikir dan merespon serta saling bantu satu sama lain. Think pair and share memberi siswa kesempatan untuk bekerja sendiri serta bekerja sama dengan orang lain. Think Pair and Share (TPS) (Adelluckyy, 2008: 24 Januari 2012) atau BerpikirBerpasangan-Berbagi merupakan jenis pembelajaran kooperatif yang dirancang untuk mempengaruhi pola interaksi siswa. Struktur yang dikembangkan ini dimaksudkan sebagai alternatif terhadap struktur kelas tradisional. Struktur ini menghendaki siswa bekerja saling membantu dalam kelompok kecil (2-5 anggota) dan lebih dicirikan oleh penghargaan kooperatif daripada penghargaan individu.

Pembelajaran kooperatif tipe Think Pair and Share (TPS) (Huda, 2011: 136) dalam cooperative lerning metode,teknik, struktur dan model penerapan, memungkinkan siswa untuk bekerja sendiri dan bekerja sama dengan orang lain sehingga bisa mengoptimalkan partisipasi siswa. Pembelajaran kooperatif tipe TPS (Adelluckyy, 2008: 24 Januari 2012) memiliki prosedur yang ditetapkan secara eksplisit untuk memberi siswa waktu lebih banyak untuk berpikir, menjawab, dan saling membantu satu sama lain. Guru perlu menerapkan langkah-langah pembelajaan kooperatif tipe TPS sebagai berikut (Adelluckyy, 2008: 24 Januari 2012).

Tahap 1 : Thinking (berpikir). Guru mengajukan pertanyaan isu yang berhubungan dengan pelajaran. Selanjutnya siswa diminta untuk memikirkan jawaban pertanyaan atau isu tersebut secara mandiri untuk beberapa saat.

Tahap 2 :Pairing (berpasangan). Guru meminta siswa berpasangan dengan siswa yang lain untuk mendiskusikan apa yang telah dipikirkan pada tahap pertama. Interaksi pada tahap ini diharapkan dapat berbagi jawaban atau berbagi ide. Guru memberi waktu $4-5$ menit untuk 
berpasangan.

Tahap 3 : Sharing (berbagi). Pada tahap ini guru meminta kepada pasangan untuk berbagi dengan seluruh kelas tentang apa yang telah mereka bicarakan. Ini dapat dilakukan dengan cara bergiliran pasangan demi pasangan dan dilanjutkan sampai dengan sekitar seperempat pasangan telah mendapat kesempatan untuk melaporkan. Berdasarkan uraian diatas, maka dapat dirumuskan tujuan penelitian ini adalah untuk meningkatkan prestasi belajar IPA dengan penerapan model pembelajaran kooperatif tipe TPS pada siswa kelas IX A semester I SMP Negeri 5 Sukoharjo tahun pelajaran 2017/ 2018. Prestasi belajar IPA siswa pada penelitian ini dibatasai pada prestasi belajar IPA materi Sistem ekskresi pada manusia.

\section{Metode Penelitian}

Penelitian ini adalah Penelitian Tindakan Kelas (PTK), atau disebut juga Classroom Action Research (CAR). Penelitian tindakan kelas merupakan suatu pencermatan terhadap kegiatan yang sengaja dimunculkan, dan terjadi dalam sebuah kelas (Arikunto, 2010: 130).Penelitian Tindakan Kelas (PTK) menurut Widayati(2008: 88)adalah suatu kegiatan penelitian yangberkonteks kelas yang dilaksanakan untuk memecahkan masalahmasalahpembelajaran yang dihadapioleh guru, memperbaiki mutu dan hasil pembelajarandan mencobakan hal-hal barudalam pembelajaran demi peningkatan mutu danhasil pembelajaran. Penelitian ini dilaksanakan di SMP Negeri 5 Sukoharjo. Tahaptahap pelaksanaan kegiatan dilakukan selama kurang lebih selama 5 (lima) bulan yaitu bulan Juli s.d November 2017. Peneliti sebagai guru IPA SMP Negeri 5 Sukoharjo bertindak sebagai subjek yang melakukan tindakan kelas. Kepala Sekolah bertindak sebagai subjek yang membantu dalam perencanaan dan pengumpulan data. Subjek yang menerima tindakan adalah siswa kelas IX A SMP Negeri 5 Sukoharjo tahun pelajaran 2017/ 2018 sebanyak 32 siswa. Teknik pengumpulan data yang digunakan adalah: (a) Tes, observasi, dan dokumentasi. Tes adalah serentetan pertanyaan atau latihan serta alat lain yang digunakan untuk mengukur keterampilan, pengetahuan inteligensi, kemampuan atau bakat yang dimiliki oleh individu dan kelompok (Arikunto, 2010 : 193). Metode tes digunakan untuk memperoleh data tentang prestasi belajar IPA siswa sebelum penelitian, selama penelitian dan setelah penelitian dilaksanakan.Observasi yang digunakan adalah observasi sistematis, yaitu observasi yang dilakukan oleh pengamat dengan menggunakan pedoman sebagai instrumen pengamatan.

Instrumen yang digunakan dalam penelitian ini adalah: lembar observasi, dan tes. Lembar observasi digunakan peneliti sebagai pedoman melakukan observasi atau pengamatan guna memperoleh data yang akurat dalam pengamatan. Lembar observasi juga digunakan untuk memonitor dan mengevaluasi setiap tindakan agar kegiatan observasi tidak terlepas dari konteks permasalahan dan tujuan penelitian. Tes digunakan untuk melihat seberapa besar prestasi dan aktivitas belajar siswa terhadap materi yang diajarkan. Hasil tes dianalisis guna mengetahui prestasi belajar siswa setelah dilakukan pembelajaran kooperatif tipe TPS. Indikator keberhasilan kinerja dalam penelitian ini adalah meningkatnya prestasi belajar siswa yang ditunjukkan dengan meningkatnya persentase ketuntasan siswa minimal $90 \%$ dan meningkatnya nilai rata-rata kelasminimal menjadi 80,00 .

\section{Hasil Penelitian}


Diketahui dengan melakukan kegiatan observasi di kelas IX A SMP Negeri 5 Sukoharjo. Kegiatan observasi awal ini dilakukan untuk mengetahui keadaan sebenarnya pada proses pembelajaran IPA yang ada di lapangan. Berdasarkan observasi awal dengan teman sejawat diketahui bahwa siswa kelas IX A memiliki prestasi belajar rendah yang disebabkan karena kurangnya perhatian dan keaktifan dari siswa saat pembelajaran dengan model ceramah. Berdasarkan hasil pretest materi Sistem ekskresi pada manusia pada siswa kelas IX A SMP Negeri 5 Sukoharjo, dari 32siswa yang mencapai nilai kriteria ketuntasan minimal (KKM) yaitu 70 sebanyak 12 siswa (37,5\%) dan siswa yang tidak mencapai nilai kriteria ketuntasan minimal(KKM) sebanyak 20 siswa (62,5\%) dengan nilai rata-rata kelas sebesar 71,7. Guru hanya menerapkan modelceramah dan siswa hanya disuruh mendengarkan dan mencatat apa yang diperlukan. Salah satu solusi yang dikembangkan adalah penggunaan modelpembelajaran kooperatif tipe TPS. Dengan penggunaan model pembelajaran tersebut diharapkan akan menciptakan suasana belajar yang berbeda, bervariasi dan menyenangkan sehingga dapat menarikperhatian siswa dan meningkatkan prestasi belajar siswa.

\section{Pembahasan}

Pembelajaran dilaksanakan dengan pedoman Rencana Pelaksanaan Pembelajaran (RPP) selama 4 jam pelajaran (4 x 40 menit). Materi yang disampaikan pada siklus I adalah cara membuat sesuatu. Model pembelajaran tipe TPS dilaksanakan dengan menggunakan langkah-langkah sebagai berikut: (1) Pendahuluan berisi kegiatan guru memberi salam, mengkondisikan kelas, dan mengecek presensi siswa. Guru menyampaikan tujuan pembelajaran yang ingin dicapai dan memberi motivasi belajar; (2) Kegiatan inti tentang pelaksanaan kegiatan model pembelajaran kooperatif tipe TPSdigunakan dari awal memberikan materi dan memberikan latihan kepada siswa, adapun langkah-langkah kegiatannya sebagai berikut: (a) guru membagi siswa menjadi 16 kelompok, tiap kelompok beranggotakan 2 siswa, teman sebangku; (b) siswa secara kelompok mendiskusikan soal pada lembar kerja tentang cara membuat sesuatu; (c) siswa secara kelompok mengembangkan langkah-langkah cara membuat sesuatu secara sempurna; (d) siswa mempresentasikan kasil kerja kelompok; (e) siswa mengkritisi presentasi kelompok lain; dan (f) guru bersama siswa memberi penguat. (3) Penutup, berisi kegiatan guru memberikan kesempatan siswa untuk menanyakan hal-hal yang kurang jelas. Kemudian guru memberikan postest, dan memberikan tugas rumah.

Dalam tahap pengamatan tindakan ini, ternyata masih banyak siswa yang kurang aktif dan masing kurang bisa beradaptasi dengan model pembelajaran yang baru. Semuanya dapat dilihat pada saat pelaksanaan pembelajaran dengan menggunakan model pembelajaran kooperatif tipe TPS. Siswa yang kurang aktif cenderung hanya mengikuti arahan dari guru. Hasil observasi menunjukkan bahwa guru telah melaksanakan kegiatan pembelajaran dengan cukup baik, yaitu guru mengajar dengan arah dan tujuan yang jelas. Namun ketika guru menyampaikan materi dengan model pembelajaran kooperatif tipe TPS, beberapa siswa tampak masih kurang memperhatikan, dan beraktivitas sendiri.Selain itu tidak semua kelompok dapat berdiskusi dengan baik. 
Setelah guru melaksanakan pembelajaran IPA dengan model pembelajaran kooperatif tipe TPS, guru melaksanakan evaluasi kepada siswa untuk mengetahui prestasibelajar siswa dalam mempelajari materi. Berdasarkan hasil evaluasi pada siklus I menunjukkan adanya peningkatan prestasi belajar siswa. Rata-rata prestasi belajar siswa pada siklus I adalah 77,2, sebanyak 23 siswa (72\%) mencapai nilai kriteria ketuntasan minimal (KKM), dan sebanyak 9 siswa (28\%) tidak mencapai nilai kriteria ketuntasan minimal (KKM). Berdasarkan hasil tersebut dapat diketahui bahwa proses pembelajaran pada siklus pertama sudah meningkatkan prestasi belajar tetapi belum berjalan dengan cukup baik serta belum mencapai indikator kinerja yang diharapkan. Keberhasilan yang dicapai setelah siklus I hanya sebagian siswa yang menunjukkan partisipasi yang meningkat sementara siswa lainnya masih pasif. Refleksi terhadap faktor-faktor yang menjadi penyebab kurangnya partisipasi siswa adalah: (1) Sebagian siswa belum bisa mengikuti langkah-langkah pembelajaran model pembelajaran kooperatif tipe TPS; (2) Kerjasama dalam kelompok berdiskusi belum maksimal; (3) Hanya siswa tertentu saja yang dapat memahami materi dan soal yang diberikan kepada setiap kelompok.

Solusi yang diambil untuk mengatasi permasalahan tersebut adalah perlu dilakukan tindakan berikutnya untuk meningkatkan perhatian dan keaktifan belajar siswa dengan meningkatkan antusias siswa untuk mengikuti pembelajaran dengan model pembelajaran kooperatif tipe TPS, guru memantau siswa pada saat pemberian materi sehingga guru dapat menegur siswa yang kurang memperhatikan dan mendorong keberanian siswa dalam mengungkapkan pendapat ketika siswa belum mengerti tentang materi yang disampaikan oleh guru. Pembelajaran dilaksanakan dengan pedoman Rencana Pelaksanaan Pembelajaran (RPP) selama 4 jam pelajaran (4 x 40 menit). Materi yang disampaikan pada siklus II adalah cara mengoperasikan sesuatu. Model pembelajaran tipe TPS dilaksanakan dengan menggunakan langkah-langkah sebagai berikut: (1) Pendahuluan berisi kegiatan guru memberi salam, mengkondisikan kelas, dan mengecek presensi siswa. Guru menyampaikan tujuan pembelajaran yang ingin dicapai dan memberi motivasi belajar; (2) Kegiatan inti tentang pelaksanaan kegiatan model pembelajaran kooperatif tipe TPSdigunakan dari awal memberikan materi dan memberikan latihan kepada siswa, adapun langkah-langkah kegiatannya sebagai berikut: (a) guru membagi siswa menjadi 8 kelompok, tiap kelompok beranggotakan 4 siswa yang heterogen,; (b) siswa secara kelompok menanggapi teks cara mengoperasikan sesuatu yang telah dibaca dengan jujur;(c) siswa mempresentasikan hasil kerja kelompok; (d) siswa mengkritisi presentasi kelompok lain; dan (e) guru bersama siswa memberi penguat. (3) Penutup, berisi kegiatan guru memberikan kesempatan siswa untuk menanyakan hal-hal yang kurang jelas. Kemudian guru memberikan postest, dan memberikan tugas rumah.

Berdasarkan kegiatan observasi, secara garis besar diperoleh gambaran pelaksanaan tindakan siklus II ada peningkatan prestasi belajar siswa. Dalam pertemuan ini banyak siswa mampu menjawab soal-soal yang diberikan dengan benar dan baik. Sebagian siswa aktif dalam bertanya dan mengemukakan ide mereka. Siswa juga dapat memahami materi yang telah diajarkan hal ini terlihat dari cara siswa menyelesaikan soal-soal. Setelah guru melaksanakan pembelajaran IPA dengan model pembelajaran kooperatif tipe TPS pada materi cara mengoperasikan sesuatu maka guru melaksanakan evaluasi kepada siswa untuk mengetahui prestasi belajar siswa dalam mempelajari materi.Berdasarkan hasil evaluasi pada siklus II menunjukkan adanya peningkatan prestasi belajar siswa. Rata-rata prestasi belajar siswa pada siklus II adalah 81,8 sebanyak 30 siswa $(93,8 \%)$ mencapai nilai kriteria ketuntasan minimal (KKM), dan sebanyak 2 siswa $(6,3 \%)$ tidak mencapai nilai kriteria 
ketuntasan minimal (KKM). Sebagian siswa menunjukkan partisipasinya meningkat dari siklus I.Keberhasilan yang dicapai setelah siklus II telah memenuhi indikator keberhasilan penelitian ini, sehingga tindakan ini tidak diteruskan atau dihentikan pada siklus II.

Berdasarkan pengolahan dan analisis data di atas, maka diperoleh interpretasi bahwa penerapan modelpembelajaran kooperatif tipe TPSterhadap peningkatan prestasi belajar IPA siswa menunjukkan terjadi peningkatan prestasi belajar siswa pada sebelum tindakan ke siklus I, pada siklus I ke siklus II. Peningkatan prestasi belajar IPA siswa sebagai efek dari meningkatnyakepercayaan diri siswa, kerjasama dalam tiap pasangan kelompok dan kemandirian dalam mengerjakan soal serta perhatiaan siswa dalam proses pembelajaran. Hal ini dapat dilihat dari hasil penelitian dari siklus pertama sampai dengan siklus kedua dapat diringkaskan seperti terlihat pada tabel sebagai berikut. Siswa yang mencapai KKM pada saat sebelum tindakan (prasiklus) sebanyak 12 siswa, setelah dilakukan tindakan siklus I sebanyak 25 siswa, setelah tidakan siklus II sebanyak 30 siswa sehingga meningkat 18 siswa.

Tabel 1. Perkembangan Siswa yang Mencapai KKM Prasiklus, Siklus I dan Siklus II

\begin{tabular}{ccccc}
\hline \multicolumn{2}{c}{ Hasil Siswa } & Prasiklus & Siklus I & Siklus II \\
¡Siswa & mencapai & 12 & 23 & 30 \\
KKM & & & &
\end{tabular}

Dari tabel di atas dapat disimpulkan bahwa prestasi belajar IPA siswa dengan menerapkan modelpembelajaran kooperatif tipe TPS, di setiap pelaksanaan tindakan, baik siklus I dan siklus II mengalami peningkatan, yaitu: siswa yang mencapai KKM Sebelum dilakukan tindakan atau prasiklus 12 siswa, setelah tidakan siklus I sebanyak 23 siswa dan setelah tindakan siklus II sebanya 30 siswa, sehingga peningkatan komulatif dari sebelum tindakan/prasiklus sampai dengan siklus II sebesar 18 siswa.

Tabel 2. Perkembangan Persentase Siswa Mencapai KKM Prasiklus, Siklus I dan Siklus II

\begin{tabular}{|c|c|c|c|}
\hline Hasil Siswa & Prasiklus & Siklus I & Siklus II \\
\hline $\begin{array}{l}\text { Persentase Siswa } \\
\text { Mencapai KKM }\end{array}$ & $37,5 \%$ & $72 \%$ & $93,8 \%$ \\
\hline
\end{tabular}

Dari tabel di atas dapat disimpulkan bahwa prestasi belajar IPA siswa dengan menerapkan modelpembelajaran kooperatif tipe TPS, pada setiap pelaksanaan tindakan mengalami peningkatan, yaitu: persentase siswa yang mencapai KKM Sebelum dilakukan tindakan atau prasiklus 37,5\%, setelah tidakan siklus I sebanyak $72 \%$ dan setelah tindakan siklus II sebanya 93,8\%, sehingga terjadi peningkatan prasiklus sampai dengan siklus II. Nilai rata-rata kelas sebelum tindakan adalah 71,7, setelah tidakan siklus I adalah 77,2 dan setelah tindakan siklus II adalah 81,8 sehingga terjadi peningkatan.

Tabel 3. Perkembangan Nilai Rata-rata Kelas Prasiklus, Siklus I dan Siklus II

\begin{tabular}{cccc}
\hline Hasil Siswa & 'rasiklus & Siklus I & Siklus II \\
\hline 1 Nilai rata-rata & 71,7 & 77,2 & 81,8 \\
\hline
\end{tabular}


Berdasarkantabel di atas dapat disimpulkan bahwa prestasi belajar IPA siswa dengan menerapkan modelpembelajaran kooperatif tipe TPS pada setiap pelaksanaan tindakan mengalami peningkatan, yaitu: nilai rata-rata kelas sebelum dilakukan tindakan atau prasiklus adalah 71,7, setelah tidakan siklus I adalah 77,2 dan setelah tindakan siklus II adalah 81,8 sehingga dari kondisi awal sebelum tindakan/prasiklus sampai dengan tidakan pada siklus II terjadi peningkatan.

Tabel 4. Siswa Mencapai KKM dan Nilai Rata-rata Prasiklus, Siklus I dan Siklus II

\begin{tabular}{llccc} 
No & \multicolumn{1}{c}{ Hasil Siswa } & Prasiklus & Siklus I & Siklus II \\
\hline 1. & Siswa Mencapai KKM & 12 & 23 & 30 \\
2. & Persentase & $37,5 \%$ & $72 \%$ & $93,8 \%$ \\
3. & Nilai rata-rata kelas & 71,7 & 77,2 & 81,8
\end{tabular}

Dari uraian di atas dapat disimpulkan bahwa modelpembelajaran kooperatif tipe TPS dapat meningkatkan prestasi belajarIPA materi Sistem ekskresi pada manusia pada siswa kelas IX A semester I SMP Negeri 5 Sukoharjo tahun pelajaran 2017/2018.

\section{Simpulan dan Saran}

Hasil penelitian ini menunjukkan bahwa model pembelajaran kooperatif tipe TPS modelpembelajaran kooperatif tipe TPS dapat meningkatkan prestasi belajarIPA pada siswa kelas IX A semester I SMP Negeri 5 Sukoharjo tahun ajaran 2017/ 2018. Hal ini dapat dilihat dari persentase ketuntasan belajar siswa, yaitu: sebelum tindakan 12 siswa atau $37,5 \%$, pada siklus I sebanyak 23 siswa atau 72,2\% dan pada siklus II sebanyak 30 siswa atau 93,8\%. Sedangkan rata-rata prestasi belajar IPA siswa sebelum tindakan sebesar 71,2, pada siklus I sebesar 77,2, dan pada siklus II sebesar 81,8. Pada siklus II nilai siswa yang telah mencapai KKM yaitu 93,8\% dan rata-rata prestasi belajar IPA siswa 81,8, angka ini menunjukkan bahwa penelitian telah berhasil, karena ketuntasan belajar siswa telah melampaui indikator kinerja yaitu $90 \%$ dan rata-rata prestasi belajar IPA siswa telah melampaui indikator kinerja yaitu 80,0.

\section{Daftar Rujukan}

Alamsyah, Nur. (2016). Pengaruh Konsep Diri terhadap Prestasi Belajar Matematika Siswa SMAN 102 Jakarta. Jurnal SAP Volume 1(2).

Arikunto, S. (2006). Prosedur Suatu Pendekatan Praktik edisi revisi 2010. Jakarta: PT Bineka Cipta.

Hamdani. (2011). Strategi Belajar Mengajar. Bandung : Pustaka Setia.

Hasanah, Zuriatun. (2021). Model Pembelajaran Kooperatif Dalam Menumbuhkan

Keaktifan Belajar Siswa. Jurnal Studi Kemahasiswaan

Volome 1(1)

Huda, M. (2011). Cooperative Learning Metode, Teknik, Struktur dan Model Penerapan. Yogyakarta: Pustaka Pelajar.

Nuharini, Dewi dan Wahyuni, Tri. (2008). Matematika Konsep dan Aplikasinya. Jakarta: Pusat Perbukuan Departemen Pendidikan Nasional.

Pratiwi, Noor Komari. (2015). Pengaruh Tingkat Pendidikan, Perhatian Orang Tua, dan 
Minat Belajar Siswa terhadap Prestasi Belajar Bahasa

Indonesia Siswa SMK Kesehatan di Kota Tangerang. Jurnal Pujangga Volume $1(2)$

Santoso, Hermawan Budi. (2017). Peningkatan Aktifitas dan Hasil Belajar dengan Metode

Problem Basic Learning (Pbl) pada Mata Pelajaran Tune Up Motor Bensin Siswa

Kelas XI di Smk Insan Cendekia Turi Sleman Tahun Ajaran 2015/2016. Jurnal Taman Vokasi Volume 5(1).

Sjafei, Irna. (2017). Pembelajaran Kooperatif dalamPengembangan Sikap pada Tugas Akademik. Jurnal Educate Volume 2(1).

Setiawati, Siti Ma'rifah. (2018). Telaah Teoritis: Apa Itu Belajar ?. Helper, Volume 35(1) $18-31$.

Sugihartono, dkk, (2007). Psikologi Pendidikan. Yogyakarta: UNY Pers.

Sunhaji. (2014). Konsep Manajemen Kelas dan Implikasinya dalamPembelajaran. Jurnal Kependidikan, Volume 2(2).

Suprijono, A. (2009). Coperatif Learning Teori \& Aplikasi PAIKEM. Yogyakarta: Pustaka Belajar.

Suryabrata, Sumadi. (1984). Psikologi Pendidikan. Jakarta: Rajawali.

Suwarto, D. (2013). Pengembangan Tes Diagnostik Dalam Pembelajaran. Yogyakarta: Pustaka Pelajar.

Suwarto, S. (2017). Pengembangan tes ilmu pengetahuan alam terkomputerisasi. Jurnal Penelitian dan Evaluasi Pendidikan, 21(2), 153-161.

Widayati, Ani. (2008). Penelitian Tindakan Kelas. Jurnal Pendidikan Akuntansi Indonesia. Volume 6(1), 87-93. 